\title{
Erratum
}

Cold Spring Harb Protoc 2020; doi: 10.1101/pdb.prot106815

\section{Erratum: Whole-Brain Calcium Imaging in Larval Xenopus}

Thomas Offner, Daniela Daume, Lukas Weiss, Thomas Hassenklöver, and Ivan Manzini

In the first published version of this protocol, the units of measure for the scale bars in Figure 1 were millimeters $(\mathrm{mm})$ rather than micrometers $(\mu \mathrm{m})$ because of unintended changes made by the compositor at the page-proof stage. The publisher apologizes for this error. The units of measure for the scale bars in Figure 1 have been corrected in the current version of the protocol. 


\section{Erratum: Whole-Brain Calcium Imaging in Larval Xenopus}

Thomas Offner, Daniela Daume, Lukas Weiss, Thomas Hassenklöver and Ivan Manzini

Cold Spring Harb Protoc; doi: 10.1101/pdb.err107425

\begin{aligned} & \hline $\begin{array}{r}\text { Email Alerting } \\ \text { Service }\end{array}$ Receive free email alerts when new articles cite this article - click here. \\ & \hline $\begin{array}{c}\text { Subject } \\ \text { Categories }\end{array}$ Browse articles on similar topics from Cold Spring Harbor Protocols. \\ & \hline\end{aligned}

